\title{
Refuge
}

Canada's Journal on Refugees

revue canadienne sur les réfugiés

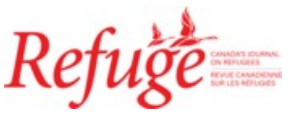

\section{The Development of the Asylum Law and Refugee Protection Regimes in Portugal, 1975-2017}

\section{Lúcio Sousa et Paulo M. Costa}

Volume 34, numéro 2, 2018

URI : https://id.erudit.org/iderudit/1055574ar

DOI : https://doi.org/10.7202/1055574ar

Aller au sommaire du numéro

Éditeur(s)

Centre for Refugee Studies, York University

ISSN

0229-5113 (imprimé)

1920-7336 (numérique)

Découvrir la revue

Citer cet article

Sousa, L. \& Costa, P. (2018). The Development of the Asylum Law and Refugee Protection Regimes in Portugal, 1975-2017. Refuge, 34(2), 28-37.

https://doi.org/10.7202/1055574ar
Résumé de l'article

Cet article examine l'élaboration, au Portugal, de la législation concernant les politiques relatives au droit d'asile et aux réfugiés. Cet examen débute en 1975, année du rétablissement de la démocratie dans le pays à la suite de la Révolution des Eillets en 1974, et s'arrête en 2015, année où débute la crise européenne de l'asile. Il s'agit pour nous de discuter si, au cours de cette période, les politiques établies signent un régime d'ouverture, dans une perspective intégrationniste, ou si elles déclarent un régime fermé, signant une position exclusiviste ; en d'autres termes, si le système d'asile promeut une politique active d'accueil et d'intégration des réfugiés, ou si les politiques poursuivies ont pour objectif de limiter l'accès des réfugiés aux frontières de l'État. Pour comprendre l'élaboration de ces politiques, nous analysons les chiffres de demandes d'asile et les lois sur l'asile en essayant de comprendre les principales circonstances contextuelles qui les infuencent, en l'occurrence l'intégration du Portugal à l’Union européenne.
Copyright (c) Refuge: Canada’s Journal on Refugees, 2018

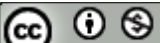

Ce document est protégé par la loi sur le droit d'auteur. L'utilisation des services d’Érudit (y compris la reproduction) est assujettie à sa politique d'utilisation que vous pouvez consulter en ligne. 


\title{
The Development of the Asylum Law and Refugee Protection Regimes in Portugal, $1975-2017^{*}$
}

\author{
LÚCIO SOUSA AND PAULO M. COSTA
}

\section{Abstract}

This article examines the development of the legislation on asylum law and refugee policies in Portugal. The assessment begins in 1975, the year when democracy was re-established in the country, following the 1974 Carnation Revolution, and ends in 2015, the year the European asylum crisis started. We want to discuss whether, during this period, the policies established indicate an open regime, with an integrationist perspective, or whether they proclaim a closed regime with an exclusivist position; in other words, whether the asylum system promoted an active policy of receiving and integrating refugees, or whether the policies pursued intended to limit the access of refugees to the borders of the state. In order to understand these developments, we analyze asylum application figures and asylum laws, trying to understand the main circumstantial contexts that influence them, namely Portugal's integration in the European Union.

\section{Résumé}

Cet article examine l'élaboration, au Portugal, de la législation concernant les politiques relatives au droit d'asile et aux réfugiés. Cet examen débute en 1975, année du rétablissement de la démocratie dans le pays à la suite de la Révolution des CEillets en 1974, et s'arrête en 2015, année où débute la crise européenne de lasile. Il s'agit pour nous de discuter si, au cours de cette période, les politiques établies signent un régime d'ouverture, dans une perspective intégrationniste, ou si elles déclarent un régime fermé, signant une position exclusiviste; en d'autres termes, si le système d'asile promeut une politique active d'accueil et d'intégration des réfugiés, ou si les politiques poursuivies ont pour objectif de limiter l'accès des réfugiés aux frontières de l'État. Pour comprendre lélaboration de ces politiques, nous analysons les chiffres de demandes d'asile et les lois sur l'asile en essayant de comprendre les principales circonstances contextuelles

* This is an updated, translated version of a chapter published as Lúcio Sousa and Paulo Manuel Costa, "A evolução do direito de asilo e regimes de proteção a refugiados em Portugal (1975-2015)," in O contencioso do direito de asilo e proteção subsidiária, ed. Sofia David, (Lisboa: Centro de Estudos Judiciários, 2016). It is reproduced with permission of the authors and the original publisher.

(C) Lúcio Sousa and Paulo M. Costa, 2018. This open-access work is licensed under a Creative Commons Attribution-NonCommercial 4.0 International Licence, which permits use, reproduction, and distribution in any medium for non-commercial purposes, provided the original authorship is credited and the original publication in Refuge: Canada's Journal on Refugees is cited.
Cette œuvre en libre accès fait l'objet d'une licence Creative Commons Attribution-NonCommercial 4.o International License, laquelle autorise l'utilisation, la reproduction et la distribution de l'œuvre sur tout support à des fins non commerciales, pourvu que l'auteur ou les auteurs originaux soient mentionnés et que la publication originale dans Refuge: revue canadienne sur les réfugiés soit citée. 
qui les influencent, en l'occurrence l'intégration du Portugal à l'Union européenne.

\section{Introduction: General Overview}

W ithin the European context, the numbers of asylum seekers and refugees in Portugal over the last forty-one years is rather small. The annual average of asylum seekers is around just 400 applications a year (figure 1). This level had been surpassed only twice, 1980-1 and 1993-4. In 2015, the number of asylum applications increased, with 872 applications. However, in view of the figures recorded in Europe, the number of asylum seekers in Portugal is a relatively peripheral phenomenon. ${ }^{1}$

Until the 1980s, most asylum applications came from former Portuguese colonies, mostly Angola and Mozambique. This post-colonial configuration decreased with time and was replaced in the 1990 os by other African countries, such as Serra Leone and Liberia. Over the last ten years, the patterns of the country of origin changed, with applicants coming from Eastern European countries, like the Ukraine, Asia (Pakistan and Afghanistan), and South America (mostly Colombians). In recent years there has also been a perceptible increase in applicants from Syria. ${ }^{3}$

The meagre data available regarding recognized refugees in Portugal ${ }^{4}$ allow us to conclude that few have been granted refugee status. In fact, despite the number of applications submitted, refugee status, including residence permits for humanitarian reasons, was granted to only 1,605 people: 741 concessions for refugee status and 864 on humanitarian grounds (figure 2). Refugee status was granted to more people in the 1980 os. From the 1990s, permits given for humanitarian reasons surpassed refugee status concession figures.
Figures for the refugee population can be analyzed using UNHCR data. ${ }^{6}$ According to its numbers, between 1976 and 1983, there were 7,600 people considered as refugees. We believe this number can be understood only within the social context at the time, with many people coming from former Portuguese colonies. We cannot forget that, in the aftermath of decolonization, between 1975 and 1977 around 500,000 people returned to Portugal from the former colonies.7

After this brief overview of the main figures on asylum seekers and refugees in Portugal, we turn to an analysis of asylum law and refugee regimes in Portugal. We have divided our approach into five main stages, following the legislative production on asylum, asylum seekers, and refugees, seeking to ascertain key features of the legal regime in force for each of them.

\section{The Carnation Revolution: Post-colonial Refugees and Returnees, 1974-1980}

In 1960 Portugal signed and ratified the 1951 Geneva Convention on the Status of Refugees. However, Portugal ratified the 1967 New York Protocol only in 1976. In the 1960s Portugal was mostly a country of origin of refugee flows: political exiles, opponents to the Estado Novo regime, and the colonial war refugees. In fact, since 1960, hundreds of thousands of refugees, comprising population and freedom fighters from the independence movements, took refuge in neighbouring countries, accounting for 50 per cent of refugees in Africa. ${ }^{9}$ For propaganda purposes, the regime also claimed to receive refugees, such as the 6,600 who arrived in Angola from the Republic of Congo in $1960 .^{10}$

In 1974 the Carnation Revolution of 25 April overthrew the forty-one-year-old Salazar-Caetano regime. Between

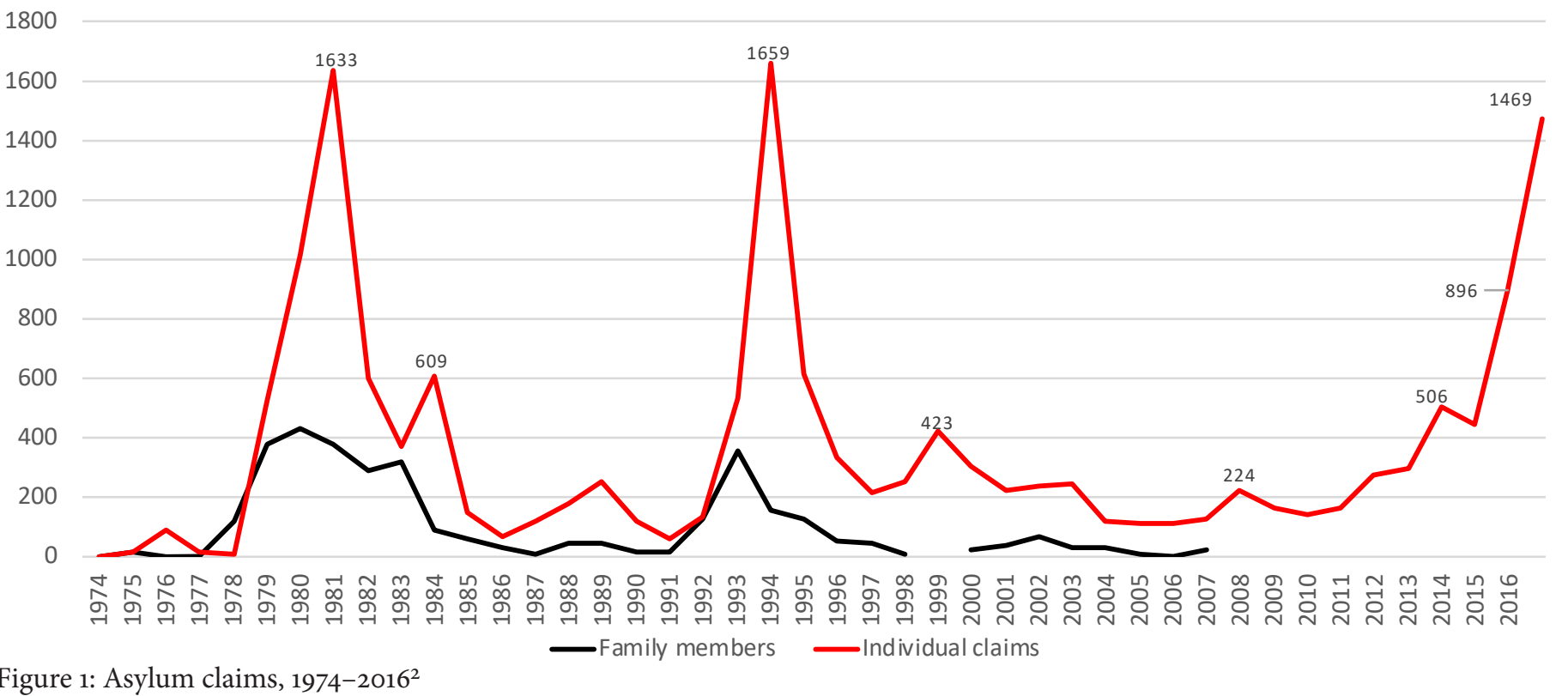




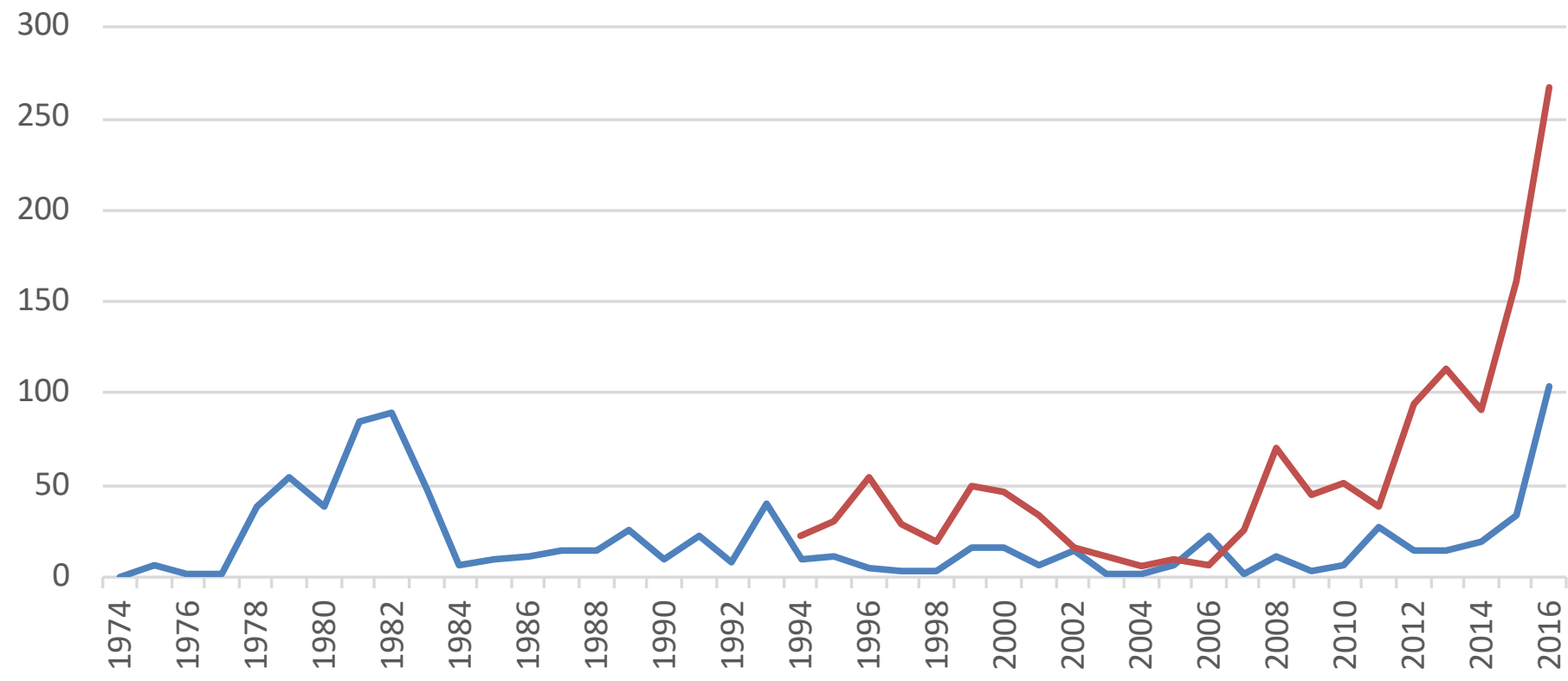

Refugee status - Humanitarian Status

Figure 2: Concessions of refugee and humanitarian status, 1974-2016

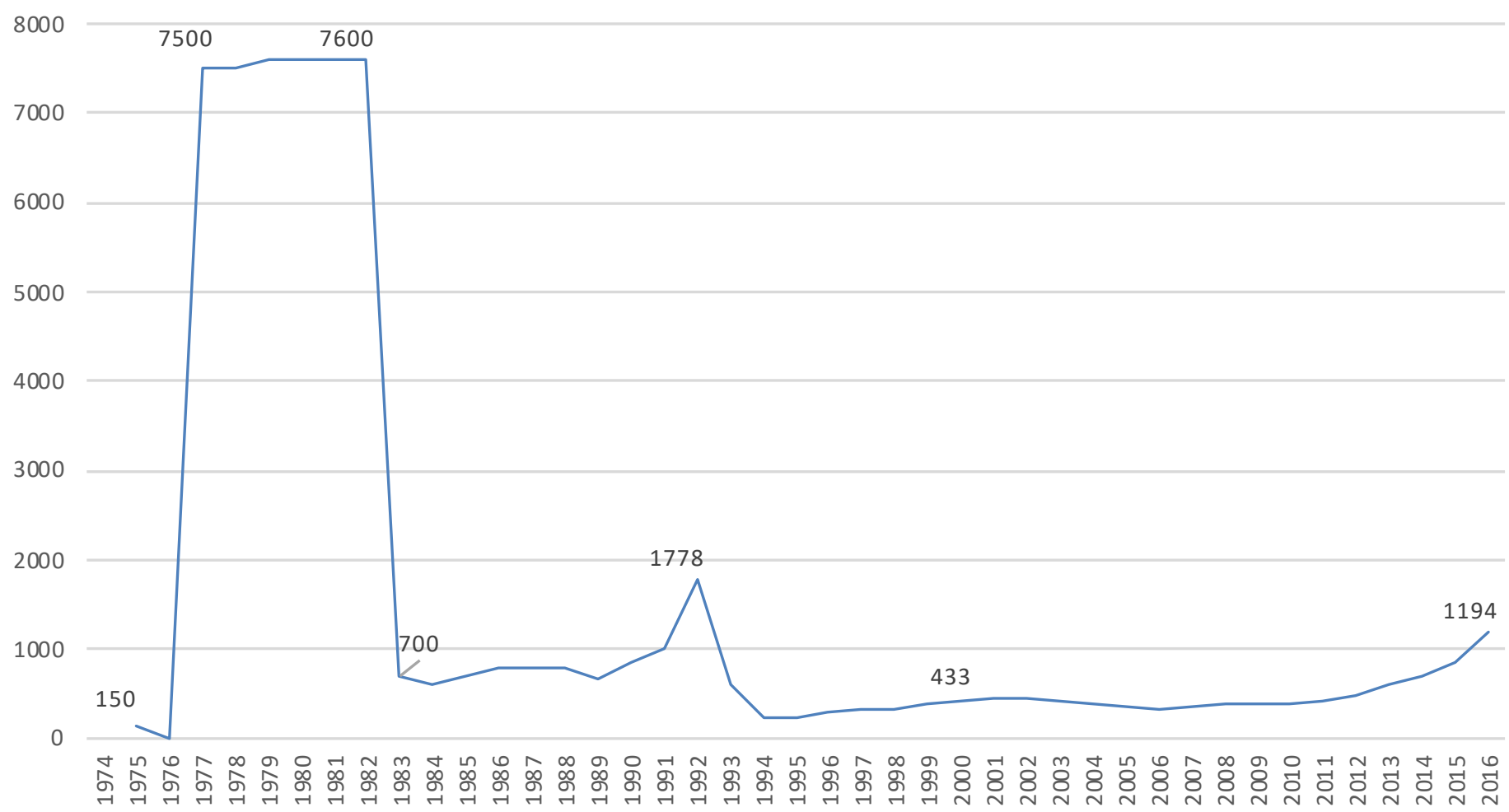

Figure 3: Refugee population in Portugal, 1974-2013 ${ }^{8}$ 
1974 and 1980 Portugal had no national legislation on asylum. Nevertheless, article 22 of the new 1976 Constitution $^{11}$ recognized the right of asylum. Between 1975 and 1977 most applicants came from Spain and South America, essentially Brazil and Chile. ${ }^{12}$ Given the absence of national legislation, the UNHCR, who meanwhile established a country office, recognized refugee status under its mandate.

In 1978 the First Cooperation Agreement between Portugal and UNHCR was established to support the social integration of people from the former Portuguese colonies with a "likelihood of refugee status." The relationship between the "refugee support process" and decolonization involved "individuals without proof of Portuguese nationality." So, for the Portuguese authorities, the issue of refugees was centred on the Africans who followed the exodus of returnees and whose nationality was doubtful, especially after the approval of decree-law no. $308-\mathrm{A} / 75$, of 24 June, ${ }^{13}$ which left thousands of "ex-Portuguese" Africans in a "legal limbo in their nationality." 14

In this context, it is worth mentioning that, between 1978 and 1984, the number of asylum seekers who obtained Portuguese nationality was almost two and a half times higher than the number of refugees who had obtained refugee status between 1974 and 1993. ${ }^{15}$ The fact that the overwhelming majority of these were made by applicants from the exPortuguese colonies in Africa indicates the close connection between the decolonization process, the amendment of the Portuguese nationality law, and how the right of asylum was used to solve the situation.

\section{A Generous Asylum Law: 1980, Progress, and Setbacks}

At a time when some European countries were already establishing restrictive legislation on asylum, ${ }^{16}$ the first Portuguese asylum law, law 38/80, of 1 August, is considered "extremely generous." ${ }^{17}$ In fact, the law provides for asylum on political grounds and for humanitarian reasons. Thus, although abiding by the Geneva Convention, the law is preceded in article 1 by a broader concept:

1. The right of asylum to aliens and stateless persons persecuted as a result of their activity in favour of democracy, social and national freedom, peace between peoples, freedom and human rights, exercised respectively in the state of their nationality or habitual residence.

Article 2 described asylum for humanitarian reasons: ${ }^{18}$ "Asylum may also be granted to foreigners and stateless persons who do not wish to return to the state of their nationality or habitual residence on grounds of insecurity due to armed conflict or the systematic violation of human rights therein."
According to article 4 (2), granting asylum on the basis of article 2 gave the beneficiary a status analogous to that of a refugee, which would be lost in time. The effects of asylum were extended to spouses and minor or disabled children of the applicant, and could also include other members of their household. As for asylum seekers, they were granted a temporary residence permit, valid until the final decision.

However, the legislation was amended in 1983 by decreelaw no. $415 / 83$ of 24 November. The alterations focused on procedural issues and resulted in a reduction of the protection afforded asylum seekers. In terms of the application, a distinction was made between those who entered Portuguese territory illegally and who should immediately submit the request, and those who entered legally, who could do so, in writing and in Portuguese within sixty days.

In addition, the notion of a preliminary refusal to asylum applications (article 15a) was introduced for those considered to be "manifestly unfounded" (e.g., no substance to the applicant's claim or deliberate deception).

Despite the introduction of these restrictive measures, the situation of asylum seekers did not deteriorate immediately. On the one hand, the number of asylum seekers was small, and most cases were handled using the normal procedure, albeit in an increasingly time-consuming manner; on the other hand, there was still relatively broad social support.

The 1980s began with the structuring of the reception and integration mechanisms of applicants, with the transition from a system of ad hoc measures applied by different institutions (inherited from the 1970s) to a model valid to all applicants. Nevertheless, in the early 1980s the phenomenon of refugees was still strongly linked to decolonization.

\section{European Union Integration: The 1993 Asylum "Crisis"19}

The beginning of the 1990s marked a withdrawal of mechanisms for the reception and integration of asylum seekers and refugees. This retraction begins with the end of much of UNHCR's support in 1991.

In 1993 the Portuguese authorities, faced with an increased number of asylum seekers, ${ }^{20}$ approved a new asylum law, initially vetoed by the president of the republic, law no. 70/93, 29 September. This law incorporated the principles of the Dublin Convention ${ }^{21}$ and Schengen Agreement, ${ }^{22}$ both of which Portugal had signed. The convention makes the state responsible for examining asylum applications and outlines a common external border, the most visible feature of the increasingly restrictive measures on access and reception of asylum seekers at the European level.

In the new asylum law two types of evaluation procedures were instituted: the "normal procedure" and the "expedited procedure." The "normal procedure" was intended for 
applications considered to be "reliable," while the "expedited procedure" was for applications that were considered "manifestly unfounded." Applications for claimants coming from a country "qualifying as a safe country or host third country" were also subject to the accelerated procedure. "Safe countries" were understood as countries for which there were no reasons to justify the existence of refugees, like the respect for human rights, democratic institutions, and its ordinary running. "Host third countries" are countries considered to be "safe," which applicants have passed through and from which they could have obtained protection or to which could have submitted applications.

The safe country concept, promoted by the European (and national) legal system of asylum, created a legal fiction that allowed European states to avoid the international obligations, in particular those arising from the Geneva Convention. As all European Union countries are considered safe, and many still have readmission agreements with neighbouring countries, many applicants can be sent back to those countries without the merits of their applications being examined. This wall was created around Europe, in practice preventing potential refugees from accessing an organized asylum assessment system.

The extension of refugee status to family members and the possibility of reunification is restricted to spouses and minor children who are single and incapacitated or, in the case of a minor, to the parents. Lodging an appeal, both in normal and accelerated proceedings, no longer has suspensive effect, meaning that the decision to leave the country can be immediately enforced to those applicants.

Like the previous law, law no. 70/93 continued to allow refusal of asylum whenever "internal or external security justifies it or when the protection of the population so requires, considering the country's social or economic situation" (article $4(2)$ ). If internal or external security reasons are understandable, refusing asylum for social or economic considerations is unjustifiable. This is all the more incomprehensible when we consider that Portugal has never been a destination for significant numbers of refugees.

\section{Specific Europe and National Features: The 1998 Law}

Although the number of asylum seekers decreased in the late 1990 s, the legal regime for asylum continued to be restrictive. With the approval of law no. 15/98, 26 March, protection for humanitarian reasons became regulated in article 8 , the most significant change being the provision that the residence permit for humanitarian reasons "is granted," instead of "exceptional." As a result, this reduced the discretion on decisions on humanitarian grounds as provided for in the exceptional regime of law no. 70/93.
The main innovation of law no. 15/98 was the regulation of a procedure for the admissibility of asylum applications. The exclusion criteria set out in the Geneva Convention and the criteria of the Schengen Agreement and the Dublin Convention, particularly the concepts of safe country of origin and host third country, are the criteria of inadmissibility (article 13).

In practice the inclusion of these criteria of inadmissibility prevents, in the Portuguese case-due to its geographical situation-any application for asylum made at the land border, so asylum seekers can arrive in Portugal only by sea or air. The implementation of this type of procedure stems from a process of legal and administrative harmonization with the other European Union countries.

However, law 15/98 introduced a role for the $\mathrm{UNHCR}^{23}$ and the Portuguese Council for Refugees (CPR) to monitor the process and provide legal support for the social aspects of asylum seeker reception. The concept of "human dignity" is presented as a key value on which social support should be based. Another important aspect was the possibility of transferring reception tasks to non-governmental organizations. In this context, a temporary reception centre with twenty-three seats was opened by the CPR to welcome asylum seekers, pending a decision on the admissibility of their application.

Another important development was the possibility of temporary protection (article 9$)^{24}$ for "displaced persons from their country, as a result of serious armed conflicts that give rise to largescale flows of refugees." It is important that this standard, although attributing a different legal status, refers to these people as "refugees"-implicitly recognizing that the concept of refugee is much broader than that provided for in article 1 , which covers only what we might call "classic refugees." ${ }^{25}$ However, this recognition of a broader concept of refugee did not translate into the extension of the asylum regime but rather into the creation of temporary and precarious forms of protection, which do account for the impact that the events that gave rise to the flows of people have on their lives and the difficulties that usually lead to an immediate return to the country of residence or nationality.

In 1998 Portugal twice provided temporary protection. One with 2,000 Kosovar refugees, although protection was granted for up to six months (Council of Ministers resolution no. 44/99, 25 May). The refugees were dispersed throughout the country, supported by a larger number of entities, including local ones. ${ }^{26}$ The other occasion involved the refugees from the former Portuguese colony of GuineaBissau. According to the Council of Ministers Resolution no. 94/98, 14 July, temporary protection was granted to Guineans coming directly from Guinea-Bissau, whose physical safety had been directly threatened as a result of the ongoing 
armed conflict. The refugees were granted an annual residence permit (ordinance no. 470-D/98, 31 July), valid for one year, which could be renewed for up to two years. Some 4,00o Guineans were expected to benefit from temporary protection. ${ }^{27}$

As of 2003 , temporary protection was regulated by law no. 67/2003, 23 August, which transposed into the Portuguese Directive 2001/55/CE, of the Council of the European Union, 20 July. ${ }^{28}$ The temporary protection procedure would be activated whenever there is a massive influx of people, meaning the arrival of "many displaced persons"; its implementation depends on a decision of the Council of the European Union that there is a massive influx of people and thus emphasizes a political component in this humanitarian intervention to ensure a balanced distribution of the effort by each European state. Protection can be guaranteed to those who have left their country or region of origin voluntarily or through an evacuation program, because of armed conflict or endemic violence, or because they are at risk or have been victims of systematic and widespread violations of human rights.

The duration of the temporary protection is one year, extended for periods of six months up to one year. Under exceptional circumstances, this period can be extended for a further year by a decision of the Council of the European Union, which means that temporary protection can be provided for up to three years. Once the temporary protection period has expired, and in accordance with article 22 (2), the beneficiaries "have a duty" to return to their country, although they may benefit from the possibility of postponing return to the country of origin (article 25).

During temporary protection, beneficiaries may apply for asylum, and the application must be considered by the Portuguese state, as the latter accepted the transfer of such people to Portuguese territory. ${ }^{29}$

Last, law no. $15 / 98$, article 27 , also provided for the resettlement of refugees under the UNHCR's mandate. Only in 2006 would this resettlement mechanism be used, with seventeen refugees being accommodated (SEF, 2006, 45). Later, in 2007, Resolution of the Council of Ministers no. 110/2007, 21 August, created a refugee reception program for the resettlement of a minimum of thirty persons every year. Between 2006 and 2014 this program enabled the resettlement of 180 refugees. ${ }^{30}$

Following the adoption of directive 2003/9/EC, 27 January 2013, which established minimum standards for the reception of asylum seekers and the need to transpose them into national legislation, law no. 20/2006, 23 June, was adopted, which approved "additional provisions of the legal framework on asylum and refugees, established by law no. 15/98." The aim was to ensure minimum material conditions that guaranteed a decent standard of living for refugees and comparable living conditions in all member states (recital 7 of directive 2003/9/EC).

\section{More Definitions, More Ambiguity: Law No. $27 / 2008$}

In 2008 a new asylum regime was approved: law 27/2008, 30 June, which transposed three European directives: directive 2004/83/EC; directive no. 2005/85/EC; and directive 2003/9/EC.

Law no. $27 / 2008$ renamed the former "safe country" as "safe country of origin." Nevertheless, this definition is unclear, since it is considered to be the country "in respect to which the applicant has not invoked any serious reason for considering that it is unsafe"; if we take into account that, in accordance with article 19 (2) (D), a safe country of origin is a reason to consider an application unfounded and inadmissible and, as such, subject to expedited procedure. It is not clear how the country of origin is considered safe or not. In directive 2005/85/EC, the concept of safe country is clearer (article 31), referring to a common list of countries that are considered safe.

Also, in the case of the "safe third country," the definition of law no. 27/2008 leaves much to be desired in t clarity, particularly regarding the rules set out and understanding the "link" that allows the person to go to the safe third country. In this case, the law merely transcribes article 27 (2) of directive $2005 / 85 / \mathrm{EC}$, a copy-paste formula that causes too many doubts.

Granting a residence permit for humanitarian reasons is now referred to as "subsidiary protection" (article 7). The situations that can be covered are both a little more specific and broader. Subsidiary protection may, therefore, be granted to people who are prevented from returning or unable to return to the country of nationality or residence because of a serious threat to their life or physical safety, as a result of "indiscriminate violence in situations of international or internal armed conflict or a widespread and indiscriminate violation of human rights." In addition to these situations, subsidiary protection may also be granted to people who are at risk of being subjected to the death penalty or to torture or to inhuman or degrading treatment or punishment.

The concept of "international protection" was also incorporated into the law, which is intended to designate refugee status and subsidiary protection status.

The consequence is that any procedure previously organized to deal with asylum applications is now used to assess applications for international protection (whether asylum or subsidiary protection). Given that the care to be taken in asylum applications is necessarily distinct from subsidiary protection, this "disappearance" of asylum in the law is not a good sign and, above all, cannot translate into lesser guarantees for applicants. The determination of the type of request 
Table 1. Policies for the admission and reception of asylum seekers and refugees in Portugal

\begin{tabular}{|c|c|c|}
\hline Phase & Statutes & Admission policies \\
\hline $1974-1983$ & Asylum seekers and returnees from the PALOP & Receptive posture \\
\hline $1983-1993$ & Asylum seekers and resettlement & Introduction of restrictive measures \\
\hline 1998-2008 & $\begin{array}{l}\text { Asylum seekers, resettlement and "temporary } \\
\text { refugees" }\end{array}$ & $\begin{array}{l}\text { Exclusive posture; diversification of the legal stat- } \\
\text { utes with greater discretion regarding concession }\end{array}$ \\
\hline 2008-2017 & International protection & \\
\hline "Relocation" & $\begin{array}{l}\text { Increasing harmonization of national policies of EU } \\
\text { states; attempt to establish a European system of } \\
\text { admission. Implementation of an European "reloca- } \\
\text { tion" program. }\end{array}$ & \\
\hline
\end{tabular}

cannot be definitive and will have to be flexible to adapt to the information gathered; in addition, and as appears logically from article 10 (2), refusing to grant the right of asylum must oblige the authorities to verify to what extent subsidiary protection may be given to applicants.

\section{The 2015 European Asylum Crisis: The "Burden" of the Relocation Process}

The influx of migrants and refugees into the EU peaked during 2015, with around one million migrants arriving in Europe, mainly in Greece and Italy. ${ }^{31}$ It was a year of crisis and highlighted the limitations of the Common European Asylum System and solidarity among Eu countries. According to the European Commission's initial proposal, Portugal was to take around 2,00o people (relocation and resettlement combined); nevertheless, the country accepted 4,500, later increasing this figure to 10,000 relocated refugees. ${ }^{32}$ The reasons for this move are manifold: for the first time, civil society was eager to be involved in the humanitarian effort, both abroad and in the country, with many institutions, such as the church and town councils stepping in, offering to receive refugees.

So, politically speaking, accepting thousands of relocated refugees was an opportunity, providing internal solidarity, and, within the EU context, expressing external solidarity by a peripheral country that had been burdened with an economic crisis amid general indifference from Europe. At the same time, there were economic and demographic considerations, as the country lacks skilled workers and has a very low birthrate. 33

Nevertheless, until July 2017 the number of relocated people was just 1,400 (out of 2,951 relocated assigned to Portugal from Council decisions), many of whom have moved to other countries, mostly in central Europe, where family networks are established. ${ }^{34}$

The length of the relocation process, particularly the small number of people actually relocated, has been one of the most significant criticisms of the European institutions, due to the impact this has on people waiting for a decision in precarious conditions.

This is happening because the Common European Asylum System is not sufficiently consolidated. There are specific rules for determining which member states deal with refugees' applications for international protection, which, in principle, would be the country where refugees first entered European territory, namely Greece and the Italy. However, as we have seen, the system was not prepared to deal with a significant influx of people and has been incapable of finding alternative answers to the difficulties that Eu border states have endured. At the same time, there has been no efficient redistribution mechanism for the other member states, which would facilitate national efforts.

This relocation process highlights the difficulty of reconciling the desire to create a European system for responding to requests for refugee protection, while its implementation is referred exclusively to national institutions.

Portugal's geographical location seems to protect it from the dramatic situations on the Greek and Italian borders, which is all the more significant, as there are no national structures capable of responding to refugees' needs. In this sense, this new experience of hosting refugees could produce changes in national policy and a new approach to refugee reception, particularly in response to the economic and demographic needs of the country. 


\section{Conclusion}

Portugal does not have a great tradition of receiving asylum seekers. The most significant refugee flows prior to 1974 were during the Second World War, when the flows mostly continued to other countries, like the United States.

In the period under analysis, Portugal received approximately 19,000 asylum applications, one of the lowest in Europe. ${ }^{35}$ However, its policies of admission and reception have developed in a similar way to those that Muus ${ }^{36}$ identifies in the Netherlands. Although the actual conditions differ from country to country, it is important to note that from an initial model of inclusion, with a relatively open asylum system, there is a transition leading to exclusion and closed asylum system.

How asylum regimes evolve is linked not only to the number and types of request but also to political circumstances, as Milner points out. ${ }^{37}$ In Portugal, this development is closely linked to the process of national asylum policy harmonization promoted by the European Union, which, to a certain extent, sought to create a European regime for the admission of refugees. Although the use of the concept of international protection reveals a broader concept of refugee within Europe, it cannot be used as a way to reduce the protection afforded to people who should benefit from the right of asylum, nor can it ignore their personal condition and the impossibility of returning to their country of origin or residence.

Refugee admission policies in Portugal can be divided into five phases.

At first, after 1974, with the exception of Brazilian and Chilean refugees, the link between decolonization and the influx of refugees from the former colonies is clear. Thus, we can say that the period between 1974 and 1983 is typically "domestic," a post-colonial legacy. Indeed, the overwhelming majority of recognized asylum seekers and refugees came from Portuguese-speaking African (PALOP) countries, most notably Angola and Mozambique.

From 1980 to 1990 , a legal and social structure for refugees began to be implemented. A generally liberal law and an inclusive posture characterize this period. Since 1990, and especially after 1993, the policy of asylum seekers and refugees is clearly one of exclusion. At this point, the Portuguese state reacted defensively to the increase in asylum applications, with the measures to discourage the arrival and permanence of asylum seekers. To this end, amendments to the asylum system focused mainly on procedural issues, resulting in the adoption of more expeditious procedures when examining applications. The new legal regime demonstrates mistrust of refugees by allowing the great majority of applications to be forwarded as "fast-track procedures," to avoid pressure from flows and the need to provide social support.
As the time taken for appraisal is increasingly limited, the examination of applications, and evidence in particular, depends increasingly on assumptions about all refugees and not on the individual condition of each person and his or her life history. Until 1993 aid for all asylum seekers was meagre. From that year onwards, the state delegated most of the burden of reception on NGOs, offering occasional support, creating structural pressure on them.

In 1998-9 Portugal had two cases of temporary protection with refugees from Guinea-Bissau, Bosnia, and Kosovo. These are two moments that, symbolically, also mark the position and context of Portugal before the refugees: the colonial heritage and European projection.

Since the beginning of the twenty-first century, the European context has become essential. Portugal is part of the process of establishing a common asylum system, which seeks to avoid the submission of several applications by the same people. This approach was accompanied by the adoption of measures to limit access to Europe, in particular by using safe countries and countries of origin clauses and readmission agreements. At the same time, responsibility for controlling the legality of entry conditions was transferred to private companies, under penalty of heavy fines, in order to keep refugees in buffered territories, as seen recently with the political-financial agreement reached with Turkey. The 2015 European asylum crisis confronts the eagerness to establish a common European regime, with a de facto situation, showing that the pressure generated at the external borders of certain states (such as Greece and Italy) is not offset by expedited redistribution of refugees and solidarity between states. In this context, Portugal deviated from its regular practices, as civil society stepped up in an unprecedented way, and governments saw an opportunity to foster an image of responsibility and solidarity, both at home and on the EU stage.

In the current crisis, the Central European states seem to withdraw from these common asylum mechanisms and (re) introduce national measures, effectively ceasing the Schengen principles and (re)designing borders, as if to institute new limits of inclusion and exclusion. Solidarity and shared responsibility, a principle invoked globally, seems to be eroding in Europe.

\section{Notes}

1 Although the number rose in 2015, according to Eurostat, Portugal remained one of the European countries with the fewest applicants per million inhabitants. Eurostat NewsRelease, "Asylum in the Eu Member States: Record Number of over 1.2 Million First Time Asylum Seekers Registered in 2015," 4 March 2015, http: //ec.europa.eu/ 
eurostat/documents/2995521/7203832/3-04032016-AP-EN. pdf/79oebao1-381c-4163-bcd2-a54959b99ed6.

2 Data by year: 1974-93: José Martins Barra da Costa, Exílio e Asilo (A questão Portuguesa 1974-1996) (Lisboa: Universidade Aberta, 1996); Lúcio Sousa, Percursos de Inserção de Refugiados em Portugal (Lisboa: Universidade Aberta, 1999); 1994-6: Serviço de Estrangeiros e Fronteiras (hereafter SEF), Relatório Estatístico 1996 (s.l., SEF, 1997); 1997: Portuguese Refugee Council, "Pedidos de Asilo em Portugal 2006," accessed 12 February 2012, http://refugiados.net/_ novosite/estatísticas/pa_2006.html (site discontinued); 1998-9: UNHCR, "2003 UNHCR Statistical Yearbook," http: // www.unhcr.org/cgi-bin/texis/vtx/page? docid=41d2c195c; UNHCR, "2004 UNHCR Statistical Yearbook," http: //www. unhcr.org/cgi-bin/texis/vtx/page? docid=44e5c78911; SEF, "Estatística 200o," http: //sefstat.sef.pt/Docs/Rifa_200o.pdf; SEF, “Estatísticas 2001," http://sefstat.sef.pt/Docs/Rifa_2001. pdf; SEF, "Relatório Estatístico 2002," http: //sefstat.sef. pt/Docs/Rifa_2002. pdf; SEF, "Relatório Estatístico 2003," http: //sefstat.sef.pt/Docs/Rifa_2003. pdf; sEF, "Relatório Estatístico 2004," http: //sefstat.sef.pt/Docs/Rifa_2004. pdf; SEF, "Relatório Estatístico 2005," http: //sefstat.sef.pt/ Docs/Rifa_2005. pdf; SEF, "Relatório de Actividades 2006," http://sefstat.sef.pt/Docs/Rifa_2006. pdf; sEF, "Relatório de Actividades 2007: Imigração, Fronteiras e Asilo," http: //sefstat.sef.pt/Docs/Rifa_2007. pdf; sEF, "Relatório de Imigração, Fronteiras e Asilo 2008," http: //sefstat.sef.pt/Docs/ Rifa_2008. pdf; sEF, "Relatório de Imigração, Fronteiras e Asilo 2009," http: //sefstat.sef.pt/Docs/Rifa_2009. pdf; SEF, "Relatório de imigração, Fronteiras e Asilo 2010," http: // sefstat.sef.pt/Docs/Rifa_2010. pdf; sEF, "Relatório de Imigração, Fronteiras e Asilo 2011," http: //sefstat.sef.pt/Docs/ Rifa_2011. pdf; SEF, "Relatório de Imigração, Fronteiras e Asilo 2012," http: //sefstat.sef.pt/Docs/Rifa\% 202012. pdf; SEF, "Relatório de Imigração, Fronteiras e Asilo 2013," http: //sefstat.sef.pt/Docs/Rifa_2013. pdf; SEF, "Relatório de Imigração, Fronteiras e Asilo 2014," https: //sefstat.sef.pt/Docs/ Rifa_2014. pdf. Since 2006, the SEF does not distinguish the household from the applicant. The data from 2006 and 2007 were obtained from the Portuguese Refugee Council, "Pedidos de Asilo em Portugal 2007," accessed 12 December 2012, http: //refugiados.net/_novosite/estatísticas/pa_2007. html (site discontinued); SEF, "Relatório de Imigração, Fronteiras e Asilo 2015," http: //sefstat.sef.pt/Docs/Rifa2015. pdf; 2016: SEF, "Relatório de Imigração, Fronteiras e Asilo 2016," http: //sefstat.sef.pt/Docs/Rifa2016. pdf.

3 In December 2013, seventy-four Syrians aboard a TAP airplane coming from Guinea-Bissau were sent back on grounds of false documents and pressure from local authorities on the airplane crew. Following this incident, the Portuguese government suspended flights between Guinea-Bissau and Lisbon. These were resumed only in November 2016. See Jornal de Negócios, "TAP retoma voos para Bissau," http: //www.jornaldenegocios.pt/empresas/ transportes/aviacao/detalhe/tapretoma-voos-para-bissau.
4 Sousa, Percursos de inserção de refugiados em Portugal, 78.

5 Costa, Exílio e Asilo, 335; Sousa, Percursos de Inserção de Refugiados em Portugal, 104; UNHCR, "2003 UNHCR Statistical Yearbook"; UNHCR, "2004 UNHCR Statistical Yearbook"; and SEF 2001-14.

6 UNHCR, "Total Refugee Population by Country of Asylum, 1960-2013 \& Total Refugee Population by Origin, 1960-2013," http: //popstats.unhcr.org/en/overview\#_ga=2 .95596380.1769678322.1505299377-18504437.1485564412.

7 Rui Pena Pires, M. José Maranhão, João P. Quintela, Fernando Moniz, and Manuel Pisco, Os "retornados": Um Estudo Sociográfico (Lisboa: IED, 1984).

8 UNHCR, "Total Refugee Population by Country of Asylum."

9 W.T.S. Gould, "Refugees in Tropical Africa," International Migration Review 8, no. 3 (1974): 413-43; and James Milner, Refugees, the State and the Politics of Asylum in Africa (Basingstoke: Palgrave Macmillan, 2009).

10 Agência Geral do Ultramar, Boletim Geral do Ultramar 36, no. 424-5 (1960): 437-8.

11 The right of asylum is currently provided for in article 33 (8) and (9) of the Portuguese Constitution.

12 Costa, Exílio e Asilo, 291; Sousa, Percursos de Inserção de Refugiados em Portugal, 270.

13 According to this decree-law, approved on the eve of Mozambique's independence, with rare exceptions, all inhabitants of African origin of former colonies lost Portuguese nationality. Maria do Céu Esteves (org.), Portugal, País de Imigração (Lisboa: IED, 1991).

14 The head of UNHCR's social integration service, interviewed in 1998, stated, "At that time there was that great ... confusion, whether they were refugees if they were returnees ... the Foreign Office itself at the outset if they had a Portuguese ascendant could go by nationality, if they had no nationality at the beginning and then the cases began to be pending." Sousa, Percursos de Inserção de Refugiados em Portugal, 135.

15 Costa, Exílio e Asilo, 370; Sousa, Percursos de Inserção de Refugiados em Portugal, 286.

16 Philip Muus, ed., Exclusion and Inclusion of Refugees in Contemporary Europe (Utrecht: ERCOMER, 1997).

17 Portuguese Refugee Council, Protecção dos Refugiados: Contexto Nacional, Curso de e-Learning de Sensibilização sobre Asilo e Refugiado (SAR), 6-Rev., 2-Dez-14: 2, http: //www .refugiados.net/e-learning/docs/6_contexto_nacional_ o2dez14. pdf.

18 It resembles the concept of refugee defined by the 1969 Convention of the Organization of African Unity.

19 The media depicted the situation as a "crisis," a term also used by some of the social workers interviewed. Sousa, Percursos de inserção de refugiados em Portugal, 144.

20 These figures are slightly different from UNHCR data because the figures presented by the UNHCR are rounded to 100. 
21 Approved by resolution of the Assembly of the Republic no. 34/92, of 18 December and ratified by decree of the president of the republic no. 58/92 of 18 December.

22 Approved by resolution of the Assembly of the Republic no. $35 / 93$, of 25 November and ratified by decree of the president of the republic no. 55/93, of 25 November.

23 UNHCR closed its delegation to Portugal in December 1998. The Portuguese Council for Refugees (CPR), established in 1991, becomes UNHCR national operational partner.

24 This rule would be repealed by law no. $67 / 2003$, of 23 August, which, when transposing directive 2001/55 / EC into the national legal order, has now regulated the granting of temporary protection in case of influx of displaced persons.

25 Aristide R. Zolberg, Astri Suhrke, and Sergio Aguayo, Escape from Violence: Conflict and the Refugees Crisis in the Developing World (Oxford: Oxford University Press, 1989).

26 Alto Comissariado para as Migrações, "A experiência portuguesa," http://www.refugiados.acm.gov.pt/aexperiencia-portuguesa/.

27 Alto Comissariado para as Migrações, "A experiência portuguesa."

28 This law remains in force, as it results from article 87 of law no. $27 / 2008$, of 30 June.

29 In principle, according to the Dublin Convention, the state responsible for examining the application for asylum would be the state for which the applicant entered the European Union.

30 Portuguese Refugee Council, "Reinstallation of Refugees 2006-2014," http://refugiados.net/1cpr/www/reinstalacao/ estatisticas-reinstalacao2006-2014.pdf.

31 European Commission, "Managing the Refugee Crisis: State of Play and Future Actions," https:// ec.europa.eu/home-affairs/sites/homeaffairs/files/ what-we-do/policies/european-agenda-migration/ background-information/docs/eam_state_of_play_and_ future_actions_20160113_en.pdf.

32 Paulo M. Costa and Lúcio Sousa, "You Are Welcome in Portugal': Conviction and Convenience in Framing Today's Portuguese Politics on European Burden Sharing of Refugees," Oxford Monitor of Forced Migration 6, no. 2 (2017): 49-53.

33 Costa and Sousa, "You Are Welcome in Portugal," 51; Lúcio Sousa and Paulo M. Costa, "Portugal's Position on Resettlement: A View from the Periphery of the Eu," Forced Migration Review 54 (2017): 22-3.

34 Valentina Marcelino, "Em dois meses duplicou número de refugiados a abandonar Portugal," Diário de Notícias, 24 April 2017, https://www.dn.pt/portugal/interior/em-doismeses-duplicou-numero-de-refugiados-a-abandonar-portugal-6239385.html.

35 UNHCR, "Total Refugee Population by Country of Asylum."

36 Muus, Exclusion and Inclusion of Refugees in Contemporary Europe, 78.

37 Milner, Refugees, the State and the Politics of Asylum in Africa, 4.

Lúcio Sousa is an assistant professor at Universidade Aberta, Portugal, and a researcher at the Centre for Studies on Migrations and Intercultural Relations and the Institute for Studies of Literature and Tradition. The author may be contacted a $t$ lucio.sousa@uab.pt.

Paulo Manuel Costa is an assistant professor at Universidade Aberta, Portugal, and a researcher at the Centre for Studies on Migrations and Intercultural Relations. The author may be contacted atpmcosta@uab.pt. 